\title{
KLASIFIKASI KERUSAKAN DENGAN JARINGAN SYARAF BACKPROPAGATION PADA PERMUKAAN SOLAR PANEL
}

\author{
Ninuk Wiliani'; Asrul Sani²;Achmad Taufiq Andyanto ${ }^{3}$ \\ Program Studi Sistem Teknologi Informasi ${ }^{1}$ \\ Institut Teknologi dan Bisnis Bank Rakyat Indonesia ${ }^{1}$ \\ https://bri-institute.ac.id ${ }^{1}$ \\ ninukwiliani@bri-institute.ac.id \\ Program Studi Sistem Informasi ${ }^{2}$ \\ Sekolah Tinggi Manajemen Komputer Widuri ${ }^{2}$ \\ https://kampuswiduri.ac.id ${ }^{2}$ \\ asrulsani@kampuswiduri.ac.id \\ Program Studi Teknik Informatika ${ }^{3}$ \\ Institut Sains dan Teknologi Nasional ${ }^{3}$ \\ https://www.istn.ac.id/ \\ pipiqtaufiq12@gmail.com
}

\begin{abstract}
Solar Panel is the things of several cells that can turn light into electricity. The damage of surface of the solar panel often results in many things. Ignorance of the officer causes damage cannot be overcome earlier so that it causes more severe events. The research conducted was to identify the beginning of some damage that often occurs. By using a statistical method that is applied to Artificial Neural Networks that uses statistical method are mean, variance, skewness to determine the value of accuracy of the sample test. The subject used is an image consisting of a damage image panel image. The damage identified in this study was damage caused by scratches, stains and rupture. The results of this study have an accuracy value of $90 \%$. So that it is expected to be detected early to see the occurrence of damage from the solar panel
\end{abstract}

key: Solar Panel, Damage, Artificial Neural Networks, Statistical

Intisari-Solar panel terdiri dari beberapa sel yang dapat merubah cahaya menjadi listrik. Kerusakan pada permukaan solar panel sering terjadi di akibatkan banyak hal. Ketidaktahuan dari petugas menyebabkan kerusakan tidak dapat diatasi lebih awal sehingga menyebabkan kejadian yang lebih parah. Penelitian yang dilakukan adalah mengidentifikasi awal dari beberapa kerusakan yang sering terjadi. Dengan menggunakan metode stastistik yang di aplikasikan ke dalam Jaringan Syaraf Tiruan yang menggunakan Mean, variance, dan skewness untuk mengetahui nilai akurasi dari pengujian sample. Subjek yang digunakan adalah image yang terdiri dari gambar gambar panel yang rusak. Kerusakan yang diidentifikasi dalam penelitian ini adalah Kerusakan akibat goresan, noda dan pecah. Hasil dari penelitian ini mempunyai nilai akurasi sebesar 90\%. Sehingga diharapkan dapat dideteksi lebih awal untuk melihat kejadian kerusakan dari solar panel.

Kata Kunci: Panel Surya, Kerusakan, Jaringan Syaraf Tiruan .

\section{PENDAHULUAN}

Panel surya merupakan perangkat yang dapat merubah energi sinar matahari menjadi energi listrik yang kemudian dapat di manfaatkan untuk memenuhi kebutuhan sebagian manusia. Seperti benda lainnya. Panel surya juga memerlukan perawatan agar terhindar dari kerusakan yang berarti, hal ini disebabkan karena panel surya mempunyai bahan dasar yang dapat mencemari lingkungan jika menjadi limbah karena proses daur ulang yang cukup sulit(Meemongkolkiat, 2008). Selain itu, kerusakan ini dapat menyebabkan berkurangnya efektifitas kinerja dari panel surya tersebut (Yuliananda, Sarya, \& Hastijanti, 2015).

Penelitian ini menggunakan objek berupa gambar dari panel surya yang mengalami kerusakan pada permukaannya(Zimmermann, 2006). Jenis kerusakan yang di ambil sample adalah kerusakan yang disebabkan oleh pecah akibat kejatuhan benda asing misalnya batang pohon atau benda berat lainnya, goresan yang diakibatkan oleh sentuhan dari benda tajam, dan yang terakhir noda yang diakibatkan bekas cairan kimia yang digunakan untuk membersihkan permukaan dari solar panel itu sendiri. (Permata, 2016). Bentuk citra rectangle berdasarkan objek yang di deteksi dan di lacak menggunakan metode 
pelacakan dengan metode segmentasi(Ong, Mustapha, Ibrahim, Ramli, \& Eong, 2015).

Deteksi objek merupakan tahapan penting yang banyak diterapkan dalam proses pencarian gambar, dengan auto annotation gambar dan pemahaman gambar(Pertahanan \& Lumpur, 2017). Pendekatan yang digunakan untuk proses ini ada dua, yaitu top-down dan bottom-up bisa juga kombinasi dari keduanya. Pendekatan topdown dilakukan dengan menggunakan tahap pelatihan untuk mendapatkan fitur fitur kelas atau objek. Penekatan bottom-up dilakukan dengan menganalisa fitur gambar tingkat rendah atau menengah seperti tepi atau segmen. (H, Ichwan, \& Putra, 2015).

\section{BAHAN DAN METODE}

Mendeteksi kerusakan pada permukaan solar panel terdiri dari beberapa catra, di antaranya yaitu dengan menganalisis kondisi permukaan berdasarkan citra yang di ambil (gambar) pada saat terjadi kerusakan. Image processing adalah teknik yang digunakan untuk mendapatkan citra (gambar) biner yang akan dilakukan proses normalisasi, grayscale, deteksi tepid an yang terakhir adalah melalui proses thresholding.

\section{Rancangan Penelitian}

Metode yang digunakan pada penelitian ini adalah jenis penelitian dan pengembangan yaitu Research and Development (R\&D). Jaringan Saraf Tiruan terbagi menjadi dua sub proses, yaitu sub proses pelatihan dan sub proses pengujian. Pelatihan sub proses terdiri dari mengubah ukuran, grayscalling, deteksi tepi, thresholding dan pelatihan. Sub proses pengujian juga terdiri dari pengubahan warna, grayscalling, deteksi tepi, thresholding dan pengujian.

\section{Sumber Data}

Penelitian ini menggunakan data berupa gambar berekstensi.jpg, .png

\section{Teknik Pengumpulan Data}

Gambar di ambil menggunakan kamera handphone Xiaomi MI A1 dan Samsung J7 Pro. Dan dirubah menjadi grayscalling, thresholding dan deteksi tepi yang disebut dengan data latih, yang akan di dimasukkan ke dalam database sebagai data uji pada jaringan syaraf tiruan backpropagation.

\section{Analisa Data}

Jaringan Saraf Tiruan terbagi menjadi dua sub proses, yaitu sub proses pelatihan dan sub proses pengujian. Pelatihan sub proses terdiri dari mengubah ukuran, grayscalling, deteksi tepi, thresholding dan pelatihan. Sub proses pengujian juga terdiri dari pengubahan warna, grayscalling, deteksi tepi, thresholding dan pengujian.

Gambar 1 menjelaskan diagram dari aplikasi deteksi klasifikasi kerusakan pada panel surya menggunakan jaringan syaraf tiruan backpropogation.

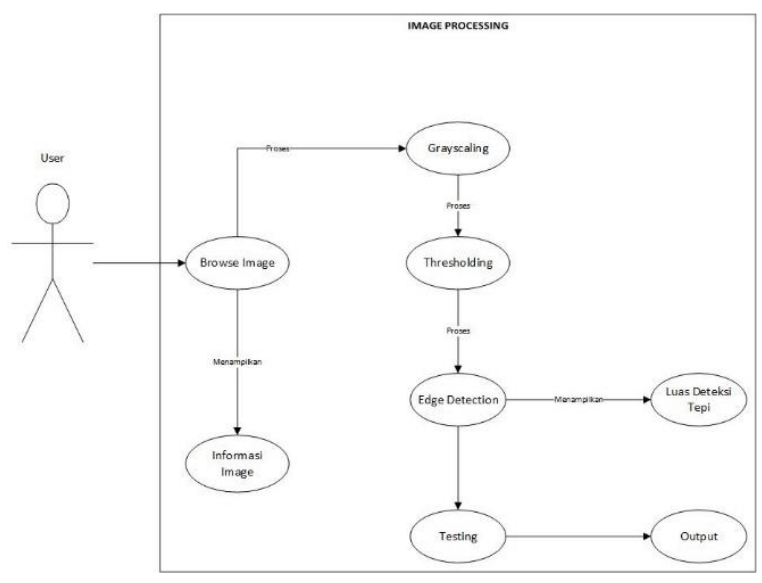

Sumber: (Andyanto, Wiliani, \& Sani, 2018)

Gambar 1. Use Case Diagram Proses Deteksi Klasifikasi Kerusakan

Tabel 1. Penjelasan dari Use Case Diagram

\begin{tabular}{|c|c|c|}
\hline NO & Nama & Penjelasan \\
\hline 1 & Browse Image & $\begin{array}{l}\text { Pada tahap ini user mengambil } \\
\text { gambar RGB dari direktori } \\
\text { penyimpanan pada laptop/PC } \\
\text { yang berkestensi .jpg. Setelah } \\
\text { memilih gambar dan muncul } \\
\text { gambar di aplikasi, secara } \\
\text { otomatis akan menampilkan } \\
\text { informasi image yang akan } \\
\text { memunculkan : Nama image, } \\
\text { ekstensi, dimensi, size (byte), } \\
\text { dan lokasi direktori image yang } \\
\text { dipilih }\end{array}$ \\
\hline 2 & $\begin{array}{l}\text { Image } \\
\text { Processing }\end{array}$ & $\begin{array}{l}\text { Setelah browse image } \\
\text { selanjutnya gambar diproses } \\
\text { untuk diubah RGB to } \\
\text { grayscaling, setelah sudah di } \\
\text { grayscaling dilanjutkan dengan } \\
\text { thresholding image dan di } \\
\text { proses untuk edge detection. } \\
\text { Setelah proses edge detection } \\
\text { secara otomatis akan } \\
\text { menampilkan luas deteksi tepi } \\
\text { yang dijadikan data latih untuk } \\
\text { jaringan syaraf tiruan ini. }\end{array}$ \\
\hline 3 & Testing & $\begin{array}{l}\text { Pada tahap ini aplikasi selesai } \\
\text { melakukan pengujian } \\
\text { menggunakan jaringan syaraf } \\
\text { tiruan dan user dapat melihat } \\
\text { hasil dari deteksi klasifikasi }\end{array}$ \\
\hline
\end{tabular}

Sumber: (Andyanto et al., 2018)(Andyanto et al., 2018) 


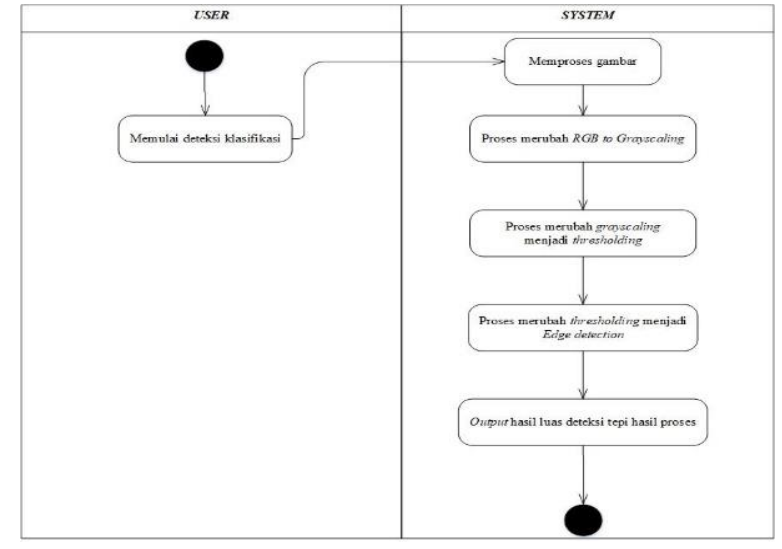

Sumber: (Andyanto et al., 2018)

Gambar 2. Activity Diagram Proses Image Processing

Pada Gambar 2 Proses Image Processing dilakukan setelah user memilih gambar kemudian proses merubah RGB menjadi Grayscaling, thresholding, dan edge detection yang digunakan sebagai data latih untuk jaringan syaraf tiruan.

\section{Perangcangan Antar Muka}

Beberapa tampilan yang dibuat menggunakan GUI (Graphical User Interface), di antaranya adalah :

Tampilan untuk mengambil gambar, tampilan gambar grayscale menjadi thresholding, tampilan merubah grayscale menjadi edge detection.

Gambar 3 merupakan tampilan antar muka utama atau tampilan awal dari rancangan aplikasi deteksi klasifikasi kerusakan pada panel surya menggunakan jaringan syaraf tiruan backpropagation.

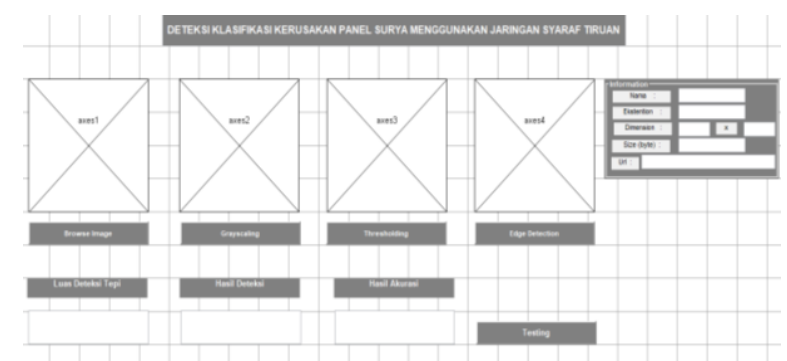

Sumber: (Andyanto et al., 2018)

Gambar 3. Tampilan antar muka utama

Tabel 2, Penjelasan user interface dari aplikasi

\begin{tabular}{lll}
\hline No. & Button & Keterangan \\
\hline 1 & Browse Image & $\begin{array}{l}\text { Untuk memilih gambar } \\
\text { dari folder } \\
\text { Untuk merubah gambar } \\
2 B G \text { ke grayscale }\end{array}$ \\
3 & Grayscaling & $\begin{array}{l}\text { Untuk merubah gambar } \\
\text { grayslace ke hitam putih } \\
\text { Untuk menampilkan luas } \\
\text { deteksi tepi } \\
\text { Untuk melatih jaringan } \\
\text { syaraf tiruan }\end{array}$ \\
\hline 5 & Edge Detection & \\
\hline
\end{tabular}

Sumber: (Andyanto et al., 2018)

\section{HASIL DAN PEMBAHASAN}

\section{Implementasi Sistem}

Implementasi dilakukan setelah analisa dengan mengumpulkan berbagai modul dari aplikasi dan di rangkai ke dalam system. Implementasi system dilakukan untuk membuktikan bahwa aplikasi deteksi klasifikasi kerusakan pada panel surya menggunakan jaringan syaraf tiruan backpropagtion berjalan dengan baik dan berfungsi sesuai dengan yang sudah di rancang.

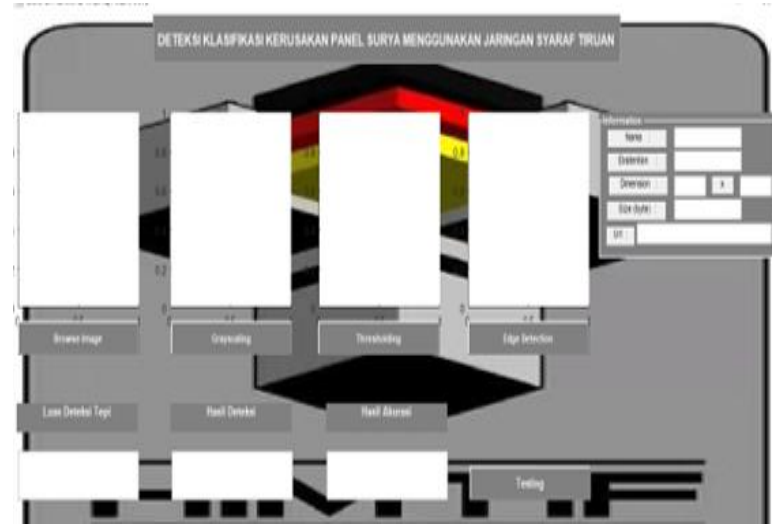

Sumber: (Andyanto et al., 2018)

Gambar 4. Tampilan program aplikasi

\section{Uji Coba Sistem}

Tiga jenis kerusakan yang du uji adalah berupa rusak (crack), goresan(scratch) dan noda(spot)(Israil, Anwar, \& Abdullah, 2013). System akan menampilkan hasil klasifikasi kerusakan terlebih dahulu dan system akan melatih dan mendeteksi kerusakan menggunakan jaringan saraf tiran backpropagation yang ada di dalam Matlab

\section{Tampilan Uji Coba Aplikasi}

Setelah dilakukan perancangan, aplikasi di buatkan sesuai rancangan. Demikian hasil dari aplikasi,

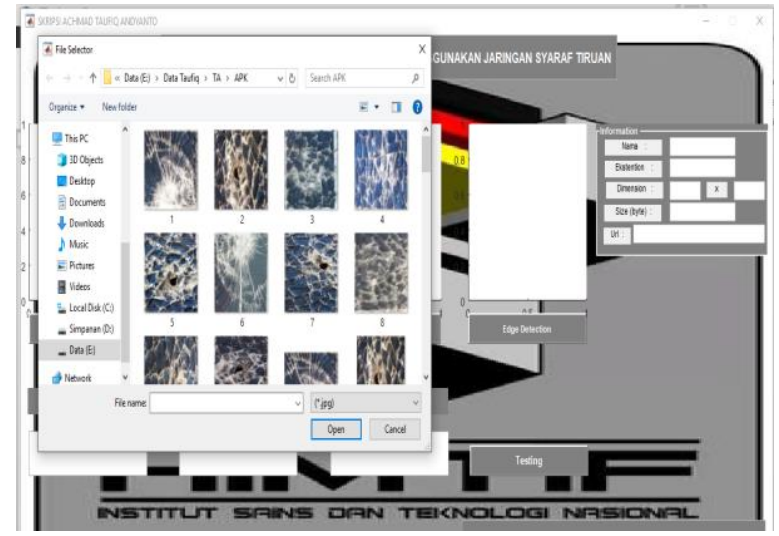

Sumber: (Andyanto et al., 2018) Gambar 5. Proses pengambilan Gambar 


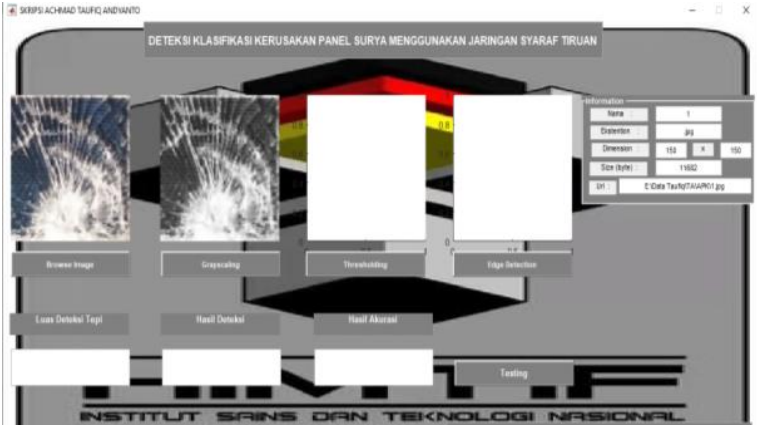

Sumber: (Andyanto et al., 2018)

Gambar 6. Browse image, Proses grayscaling

Setelah user memilih gambar pada folder, maka langkah selanjutnya adalah proses grayscaling.

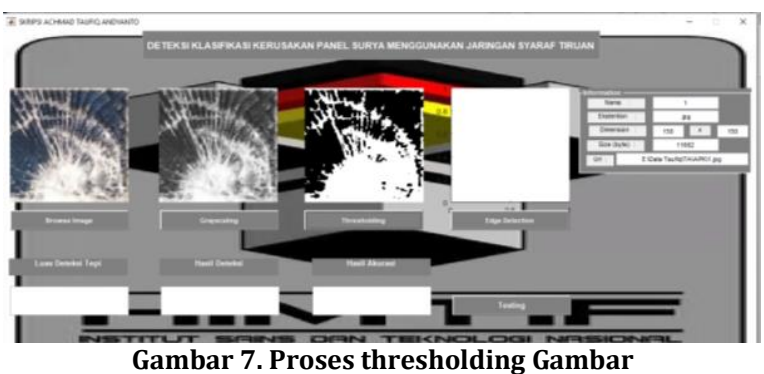

Tolong jelaskan gambar diatas

Gambr secara otomatis mengeluarkan informasi gambar yang berisi nama, gambar, ekstensi gambar, dimensi gambar, size byte gambar dan tempat peyimpanan gambar akan muncul.

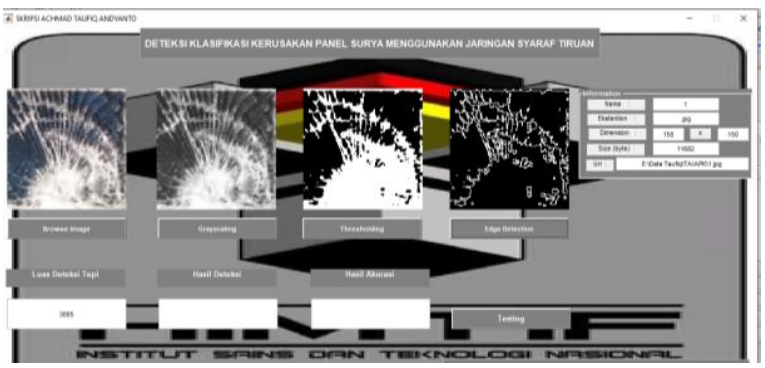

Sumber: (Andyanto et al., 2018)Gambar 8. Proses Edge Detection (deteksi Tepi)

Tolong jelaskan gambar diatas

Gambar 8 menjelaskan proses dari edge detection untuk gambar yang sama

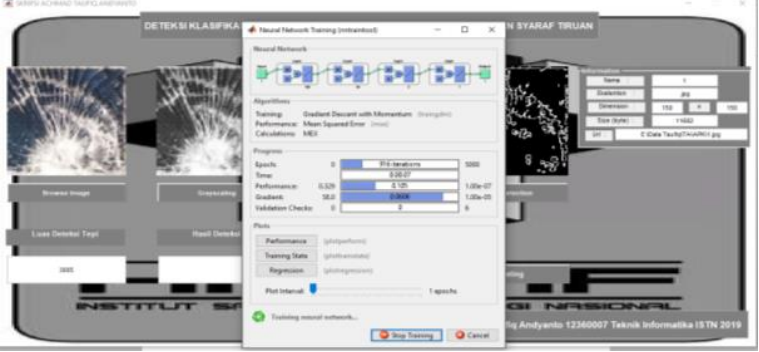

Sumber: (Andyanto et al., 2018)

Gambar 9. Proses Latih Jaringan Syaraf Tiruan backpropagation
Setelah proses dilakukan, yaitu edge detection (deteksi tepi) aplikasi akan melakukan testing untuk melatih jaringan saraf tiruan agar system bias melakukan deteksi dan mengklasifikasi kerusakan pada panel surya.

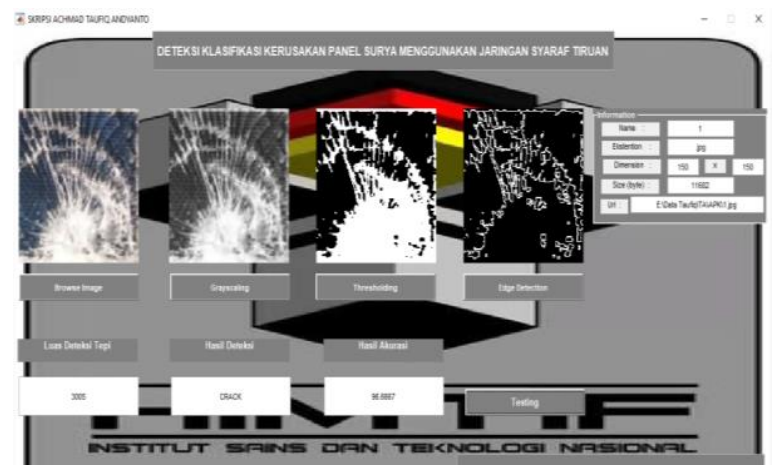

Sumber: (Andyanto et al., 2018)

Gambar 10. Hasil latih jaringan syaraf tiruan backpropogation

Tolong jelaskan gambar diatas

Setelah system dapat melatih jaringan syaraf tiruan backpropagation, maka muncul hasil deteksi kerusakna dan akurasi keruskan dan akurasi kerusakan.

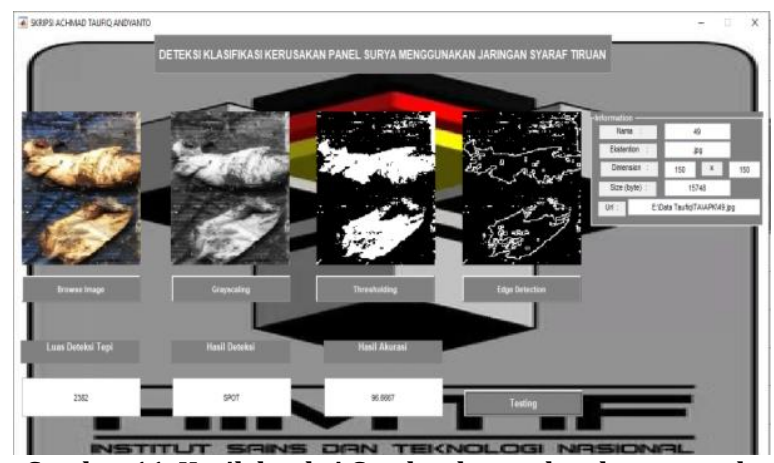

Gambar 11. Hasil deteksi Gambar kerusakan karena noda (spot)

Tolong jelaskan gambar diatas

Perlakukan yang sama dilakukan untuk gambar yang berbeda dengan hasil yang berbeda

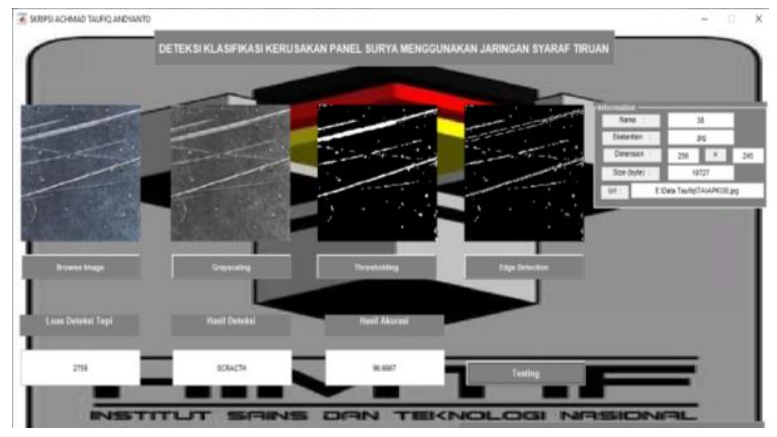

Sumber: (Andyanto et al., 2018)

Gambar 12. Hasil deteksi gabar karena goresan (scratch) 
Hasil Uji coba Aplikasi

Untuk testing, akan dlakukan sebanyak 20 pervobaan dengan tiga klasifikasi yaitu, kerusakan goresan, pecah, dan noda.

\section{Tabel 3. Hasil Dari Kesesuain Aplikasi}

\begin{tabular}{|c|c|c|c|c|c|}
\hline No & $\begin{array}{c}\text { Cutra } \\
\text { Tekstur } \\
\text { Asli } \\
\end{array}$ & $\begin{array}{c}\text { Citra } \\
\text { Tekstur } \\
\text { Grayscale } \\
\end{array}$ & Manual & Aplikasi & Hasil \\
\hline 1 & & & $\begin{array}{c}\text { Crack } \\
\text { (Rusak) }\end{array}$ & $\begin{array}{c}\text { Crack } \\
\text { (Rusak) }\end{array}$ & $\begin{array}{l}\text { Sesuai } \\
\end{array}$ \\
\hline 2 & & & $\begin{array}{c}\text { Crack } \\
\text { (Rusak) }\end{array}$ & $\begin{array}{c}\text { Crack } \\
\text { (Rusak) }\end{array}$ & Sesuai \\
\hline 3 & & & $\begin{array}{c}\text { Crack } \\
\text { (Rusak) }\end{array}$ & $\begin{array}{c}\text { Crack } \\
\text { (Rusak) }\end{array}$ & Sesuai \\
\hline 4 & & & $\begin{array}{c}\text { Crack } \\
\text { (Rusak) }\end{array}$ & $\begin{array}{c}\text { Crack } \\
\text { (Rusak) }\end{array}$ & Sesuai \\
\hline 5 & & & $\begin{array}{c}\text { Crack } \\
\text { (Rusak) }\end{array}$ & $\begin{array}{c}\text { Crack } \\
\text { (Rusak) }\end{array}$ & Sesuai \\
\hline 6 & & & $\begin{array}{c}\text { Crack } \\
\text { (Rusak) }\end{array}$ & $\begin{array}{c}\text { Scracth } \\
\text { (Goresan) }\end{array}$ & $\begin{array}{c}\text { Tidak } \\
\text { Sesuai }\end{array}$ \\
\hline 7 & & & $\begin{array}{c}\text { Crack } \\
\text { (Rusak) }\end{array}$ & $\begin{array}{c}\text { Crack } \\
\text { (Rusak) }\end{array}$ & Sesuai \\
\hline 8 & & & $\begin{array}{c}\text { Crack } \\
\text { (Rusak) }\end{array}$ & $\begin{array}{c}\text { Crack } \\
\text { (Rusak) }\end{array}$ & Sesuai \\
\hline 9 & & & $\begin{array}{c}\text { Crack } \\
\text { (Rusak) }\end{array}$ & $\begin{array}{c}\text { Crack } \\
\text { (Rusak) }\end{array}$ & Sesuai \\
\hline 10 & & & $\begin{array}{c}\text { Crack } \\
\text { (Rusak) }\end{array}$ & $\begin{array}{c}\text { Crack } \\
\text { (Rusak) }\end{array}$ & Sesuai \\
\hline 11 & & & $\begin{array}{c}\text { Spot } \\
\text { (Noda) }\end{array}$ & $\begin{array}{c}\text { Spot } \\
\text { (Noda) }\end{array}$ & Sesuai \\
\hline 12 & & & $\begin{array}{c}\text { Spot } \\
\text { (Noda) }\end{array}$ & $\begin{array}{c}\text { Spot } \\
\text { (Noda) }\end{array}$ & Sesuai \\
\hline 13 & & & $\begin{array}{c}\text { Spot } \\
\text { (Noda) }\end{array}$ & $\begin{array}{c}\text { Spot } \\
\text { (Noda) }\end{array}$ & Sesuai \\
\hline
\end{tabular}

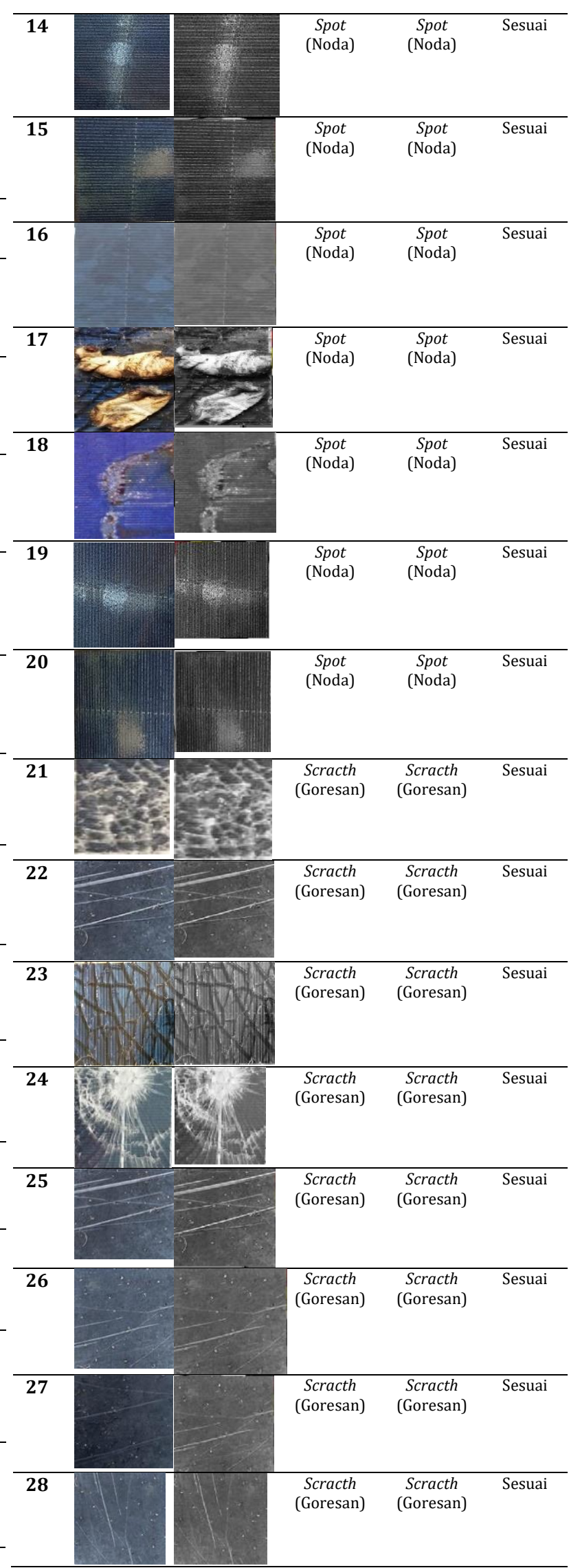




\begin{tabular}{l|llll}
\hline 29 & $\begin{array}{c}\text { Scracth } \\
\text { (Goresan) }\end{array}$ & $\begin{array}{c}\text { Crack } \\
\text { (Rusak) }\end{array}$ & $\begin{array}{c}\text { Tidak } \\
\text { Sesuai }\end{array}$ \\
\hline 30 & & & & \\
\hline
\end{tabular}

Sumber : (Andyanto et al., 2018)

Tabel 3 merupakan hasil kesesuaian antara manual dan hasil dari aplikasi untuk mengklasifikasikan kerusakan pada panel surya. Gambar yang digunakan sebagai sample yaitu sebanyak 30 gambar.

Tabel 4. Akurasi Sistem

\begin{tabular}{lcc}
\hline \multicolumn{1}{c}{ Data Uji } & \\
\hline Input & Sesuai & Tidak Sesuai \\
\hline Crack (Rusak) & 9 & 1 \\
\hline Spot (Noda) & 10 & 0 \\
\hline Scracth (Goresan) & 8 & 2 \\
\hline Akurasi (\%) & $\frac{J \text { jumlah Citra Uji Yang Sesuai }}{27} \times 100 \%$ \\
& $\frac{27}{20} \times 100 \%$ & \\
& 90 & \\
\hline \multicolumn{2}{l}{ Sumber : (Andyanto et al., 2018) }
\end{tabular}

Tabel 4 merupakan hasil perhitungan akurasi sistem, dari hasil perhitungan table ini, tingkat akurasi untuk deteksi klasifikasi kerusakan pada panel surya menggunakan jaringan syaraf tiruan backpropagation yaitu mencapai 90\% sesuai dengan hasil yang sebenarnya.

\section{KESIMPULAN}

Berdasarkan aplikasi yang telah dibuat dan uji coba yang telah dilakukan, maka, Penggunaan metode jaringan syaraf tiruan backpropagation dapat dijadikan sebagai salah satu metode untuk mengklasifikasikan / memprediksi kerusakan pada panel surya dengan presentasi 90\% Penetapan nilai learning rate 0,001 minimal nilai error yang ditentukan 0,0000001 dan untuk banyaknya iterasi percobaan (epochs) sebesar 3500 kali iterasi. Untuk hasil gambar pada penelitian ini hanya menggunakan gambar dengan ekstensi .jpg karena gambar diambil dengan kamera dengan ekstensu bawaan .jpg. Data latih dan jumlah gambar sampel akan mempengaruhi hasil dari deteksi. Semakin kecil data latih dan jumlah gambar sample akan menghasilkan nilai akurasi yang kecil.

\section{REFERENSI}

Andyanto, A. T., Wiliani, N., \& Sani, A. (2018). Laporan Akhir Penelitian: Deteksi Klasifikasi
Kerusakan Panel Surya Menggunakan Jaringan Syaraf Tiruan Backpropagation. Jakarta.

H, A. N., Ichwan, M., \& Putra, I. M. S. (2015). Segmentasi citra untuk deteksi objek warna pada aplikasi pengambilan bentuk citra rectangle, 7, 1-10.

Israil, M., Anwar, S. A., \& Abdullah, M. Z. (2013). Automatic detection of micro-crack in solar wafers and cells: A review. Transactions of the Institute of Measurement and Control, 35(5),

606-618. https://doi.org/10.1177/014233121245758 3

Meemongkolkiat, V. (2008). Development Of High Efficiency Monocrystalline SI Solar Cells Through Improved Optical and Electrical Confinement. Georgia Institute of Technology.

Ong, A. T., Mustapha, A., Ibrahim, Z. Bin, Ramli, S., \& Eong, B. C. (2015). Real-Time Automatic Inspection System for the Classification of PCB Flux Defects. American Journal of Engineering and Applied Sciences, 8(4), 504518.

https://doi.org/10.3844/ajeassp.2015.504.5 18

Permata, E. (2016). Identifikasi Obyek Benda Tajam Menggunakan Pengolahan Citra Digital Pada Citra X-Ray, 1(1), 1-14.

Pertahanan, U., \& Lumpur, U. K. (2017). Detection of Faulty Photovoltaic Panel on Thermographic Images Using Deep Learning Algorithm, 5(x)

Yuliananda, S., Sarya, G., \& Hastijanti, R. R. (2015). Pengaruh perubahan intensitas matahari terhadap daya keluaran panel surya. Jurnal Pengabdian LPPM Untag Surabaya, 01(02), 193-202.

Zimmermann, C. G. (2006). The Impact of Mechanical Defects on the Reliability of Solar Cells in Aerospace Applications, 6(3), 486494. 